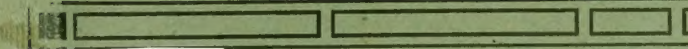

SB 110

.N3

1911-

1912

Copy 1

STATE OF NEVADA

BIENNIAL REPORT

OF THE

Elko County Dry Farm

\title{
1911=1912
}

GORDON H. TRUE,

A. W. HESSON,

GE0. M. BOWER, Board of Control

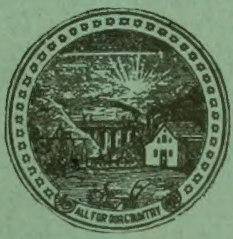





\section{STATE OF NEVADA}

\section{BIENNIAL REP0RT}

OF THE

\section{Elko County Dry Farm}

\section{$1911=1912$}

GORDON H. TRUE,

A. W. HESSON, GE0. M. BOWER,

Board of Control

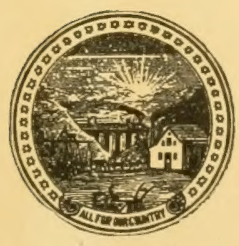

CARSON CITY, NEVADA

State Printing Office . . . Joe Farnsworth, Superintendent 1913 


$$
\begin{aligned}
& \text { SB110 } \\
& \text { N3 }
\end{aligned}
$$

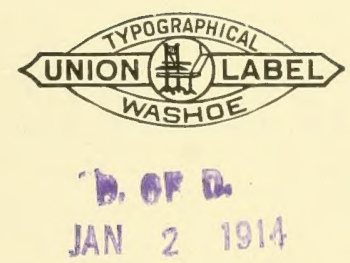




\title{
LETTER OF TRANSMITTAL
}

\author{
OfFice of the BoARd of Control \\ State Agriculitural Experiment Dry Farm,
}

Elko, Nevada, December 31, 1912.

His Excellency, Tasker L. Odde, Governor of Nevada.

Dear Sir: Herewith is submitted the report of the Board of Control of the State Agricultural Experiment Dry Farm, located at Pleasant Valley, Elko County, Nevada, for the years 1911 and 1912.

Respectfully,
A. W. HESSON,
Chairman. 


\section{BOARD OF CONTROL, ELKO COUNTY DRY FARM}

A. W. Hesson, Chairman

GEo. M. Bower

Gordon H. True, Secretary

Walfried Sohlman, Foreman of Farm
Elko Lamoille Reno Blaine, Nevada 


\section{BIENNIAL REPORT}

The State Agricultural Experiment Dry Farm was established by Act of the Legislature in 1909. The site was selected by a committee of Elko County farmers and purchased by that county and title given to the State. The property was turned over by the Governor to the Agricultural Experiment Station for management in June, 1910, and in the spring of the following year came under the management of the present Board of Control. Less than half of the appropriation for the first biennial term was spent. Only one team had been bought, no new buildings had been erected and but sixty acres of new land cleared. It has therefore been necessary to erect buildings, buy additional teams and some new machinery that might have been purchased with that part of the appropriation which was turned back to the State. This fact seemed to the State Board of Examiners to justify them in the allowance of an $\$ 1,800$ deficit in the account for 1912 , all of which has not been used.

Of the total area of the ranch probably 130 acres are now under cultivation and all the rest cleared. The only needed expenditures for equipment are for a small thresher with power, and a small building suitable for office and seed laboratory. The board estimates that the cost of running the work for two years including these expenditures for new equipment will be $\$ 8,000$, a thousand dollars a year less than the previous appropriations.

The State Dry Farm justifies continued maintenance for the following reasons:

1. It is a practical demonstration of what can be done by scientific agriculture in localities where the precipitation is 11 to 15 inches.

2. It has just arrived at the stage where the best results may be looked for. It has taken reasonable time to work up to this condition.

3. It can now be a center for distribution of good seed. With a convenient little thresher outfit added to the present equipment, pure seed of superior quality would be available for Nevada's farmers.

4. Many live problems in dry farming remain yet to be solved, many possibilities to be demonstrated. One or two might be mentioned-orchard experiment, alfalfa-seed growing, drought-resistant grass tests, and stock maintenance.

\section{REVIEW FOR 1911}

During the year 1911 the experiments were all in the field of spring crops. In the autumn of 1910 the condition of the ground did not admit of fall seeding, and not until the late autumn rains had made it practicable was any fall ploughing attempted. Therefore, while fall seeding is generally the practice in dry farm work, we were unable to do anything in this field of experiment during 1911.

The precipitation during 1911 was as follows: 


\section{Precipitation}

January . $\begin{aligned} & \text { February } \\ & \text { March }\end{aligned}$ April
May
June
July
August
September
October
November
December
Total

This record shows that the largest part of the precipitation occurred during the first five months of the year, furnishing a particularly good condition for spring germination. This was desirable where the ground had not been summer fallowed during the previous year. On the other hand, the small amount of precipitation after the second of June resulted in a severe test of the drought-resistant qualities of the crops during the summer months. Little rain fell during June, July, August, and September. Not until September 30 and October 1, when 0.98 inches fell, was there a rain to amount to much, and then it was too late to be of much use.

\section{Crops}

Following is a report of the spring-sown crops of 1911:

White Australian wheat ( 90 pounds per acre)

11.70 bushels per acre 11.03 bushels per acre

White Australian wheat ( 45 pounds per acre) 29.00 bushels per acre

Sixty-Day oats ( 40 pounds per acre) 29.50 bushels per acre Kubanka wheat (90 pounds per acre) 14.90 bushels per acre Kubanka wheat (45 pounds per acre) Minnis oats (64 pounds per acre) 14.10 bushels per acre 27.70 bushels per acre 23.70 bushels per acre Minnis oats ( 40 pounds per acre) Beardless barley ( 90 pounds per acre) Beardless barley ( 60 pounds per acre) Spring rye ( 84 pounds per acre) 27.70 bushels per acre -24.20 bushels per acre 13.40 bushels per acre Spring rye ( 42 pounds per acre) 11.40 bushels per acre

In every instance but one heavier seeding resulted in the greater yield. Of course there is a wide difference in the amounts used and it may be that some intermediate quantity of seed per acre would do better than either. It must also be stated that the more heavily seeded plots were subjected to more cultivation, resulting in loss of plants, it is true, but also in conservation of soil moisture.

A number of varieties, principally root crops, were planted in soil too dry, to secure germination in some cases, and in others to secure favorable growth. They were:

Parsnip-White Lisbon.

Parsnip-Improved Long Smooth.

Carrot-Large White Belgian.

Carrot-Improved Long Orange.

Carrot-New Long Lemon Stump.

Beet-Blood Turnip.

Beet-Imperial Sugar.

Beet-Klein Wanzleben.

Mangel-Gatepost.

Mangel-Jumbo.
Millet-Foxtail.

Millet-Broomeorn.

Millet-Barnyard.

Millet-Pearl.

White Kaffir Corn.

Standard Broom Corn.

Dwarf Broom Corn.

Dhoura Broom Corn.

Yellow Milo Maize. 
Australian White Flint corn and Swadley corn were eaten down by rabbits.

Three varieties of onions, New Commercial, White Welsh, and White Bartletta, came along fairly well. However, of the intertilled crops only potatoes and peas proved satisfactory. Seven varieties of potatoes were tested, yielding in the order given:

Peerless
Burbank
Dalmeny Challenge
Peachblow
Mammoth Pearl
Early Red
Blue Victor

Two varieties of peas were tested and yielded as follows:

Golden Vine Field

14.8 bushels per acre

Green Canada Field

17.8 bushels per acre

\section{Fall Seeding}

The area to be fall seeded had not been summer fallowed, as other work was pressing; new ground had to be cleared, fencing and building demanded attention and a war must be maintained against the small animals. Our seeding took place in September and all the seed was planted by October 1. All was planted at a depth of from five to six inches, the reason being that it appeared necessary to plant at that depth to reach moisture and secure germination. The following grains were sown:

Wheat-Turkey Red, 1656, 1559, White Australian.

Emmer-Black Winter.

Spelt.

Einkorn.

Oats-Winter Turf.

Rye-No. 1, No. 13.

Barley-Tennessee Winter.

Comment upon the results obtained and upon the work done in 1911 will be found later in conjunction with remarks upon the experiences of 1912.

REVIEW FOR 1912

In 1912 the precipitation for the year was as follows:

\begin{tabular}{|c|c|}
\hline \multicolumn{2}{|c|}{ Precipitation } \\
\hline January ...... & 1.21 inches \\
\hline February .- & .49 inches \\
\hline March ..... & 2.63 inches \\
\hline April .... & 3.45 inches \\
\hline May ...... & 1.47 inches \\
\hline June & .75 inches \\
\hline July ......... & 1.39 inches \\
\hline August .... & .22 inches \\
\hline September .... & .00 inches \\
\hline October ........ & 3.00 inches \\
\hline November & 1.02 inches \\
\hline December (10th) & .06 inches \\
\hline
\end{tabular}

As in 1911 the first five months furnished a large part of the total precipitation but the preponderance was not nearly so great as in the year previous. It is well that we call attention to certain conditions favorable 
to spring crops. The autumn precipitation in 1911 had been scanty. Up to April 1 the total precipitation for 1912 was 4.33 inches, not heavy it is true, but enough to secure good spring germination. In April we had the heavy precipitation of 3.45 inches, included in which were three rains of about one-half inch each. Following this, May gave us an encouraging amount of precipitation including three good rains. In June the fall was less, but July gave an unusual amount of rain for that time of the year. Coming as it did on July 18, the heavy rain of 1.2 inches furnished a condition favorable to complete maturity. In conclusion, 1912 handed down another favor in the unusual precipitation of October and November, which, as we had secured an early fall seeding, gave us a strong fall growth.

\section{Spring-Sown Crops}

This seed was planted on land that had not been summer fallowed during the past year. However, the winter precipitation gave us sufficient moisture for spring germination, as indicated in the previous subdivision. The spring crops gave splendid results as will be seen in the following detailed report.

1. Following is a list of crops which made a good start, and promised well, but which were practically destroyed by the frost of September 5:

Early Amber Sugar Cane.

White Kaffir Corn.

Broom Corn-Evergreen.

Broom Corn-Dwarf.

Broom Corn-Standard.

Field Corn-Swadley.

Field Corn-Imp. Leaming.

Field Corn-Pride of the North.

Field Corn-Australian White Flint.

Field Corn-Colorado Yellow Dent.

Crops of this class constitute more or less of a gamble in this region of early frosts. The chief hope is in securing early varieties and, if possible, developing from these some early and hardy strains. For the silo we see no reason why corn should not be grown profitably, necessitating particularly early cutting, but for grain production the hope lies in future development. As an off-hand suggestion we would recommend the earliest Flints for most promising experiment.

In this class the following secured a poor stand and made poor growth; this year would not indicate any durability on the part of these crops. They were: Brown Dhoura, Jerusalem Corn, Red Kaffir Corn, Shallu.

2. We had good success with millets. The stand was good as a rule, the growth was strong and the yield, considering the percentage of seed, was satisfactory. The millets were sown in rows, admitting of cultivation, a condition scarcely imperative on summer-fallowed ground. The comparative yields given below are not always indicative of comparative value from a feed standpoint. However, the hardiness, the rapid growth, and the high food-value of the millets should make almost all of the varieties profitable. This year the sample sown as Barnyard millet more than doubled most of the others in yield. Following is the report in detail: 


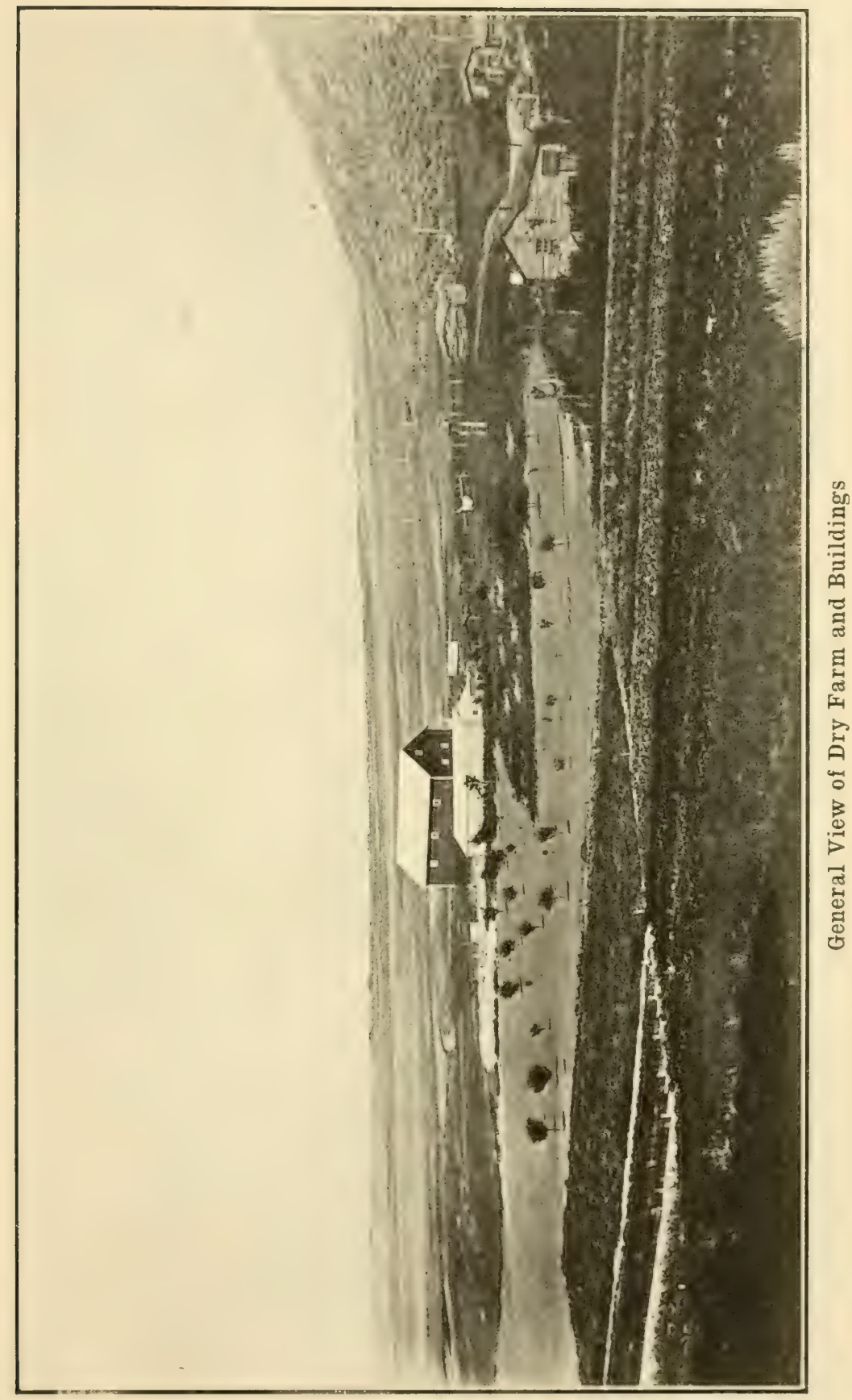




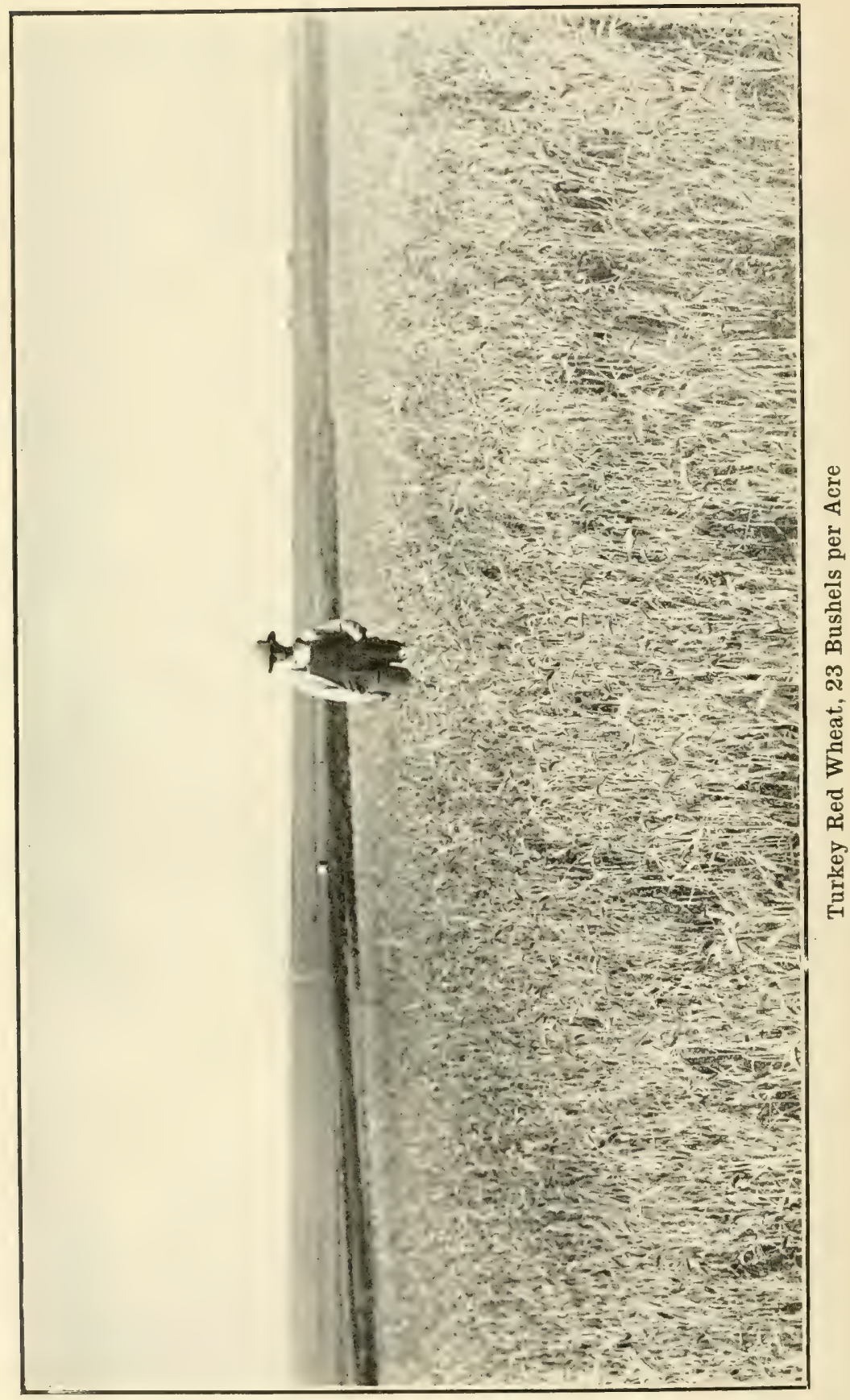




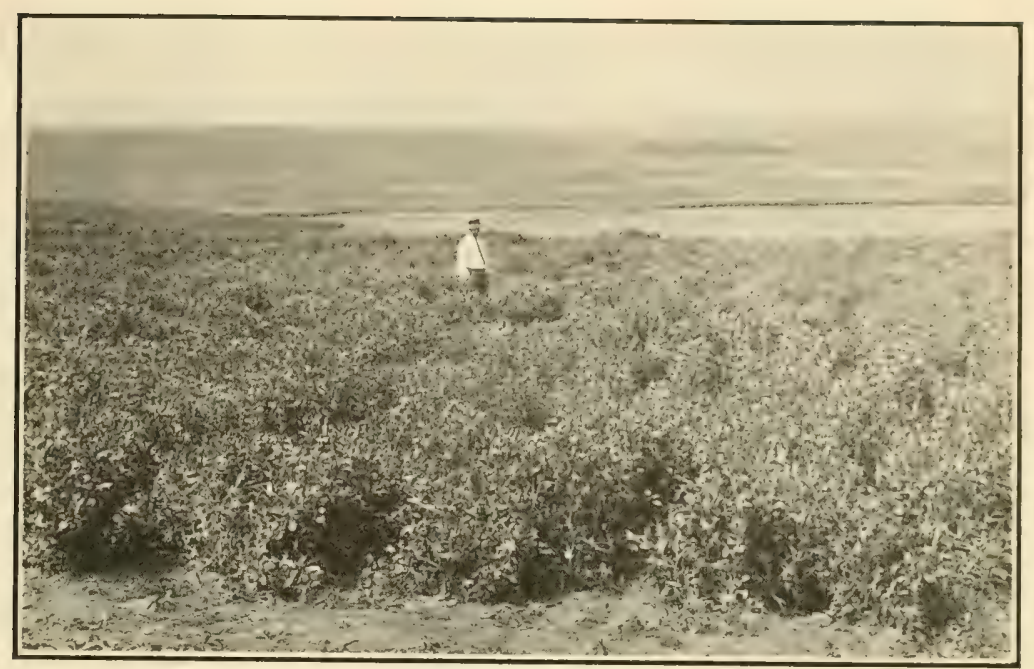

Canada Field Peas

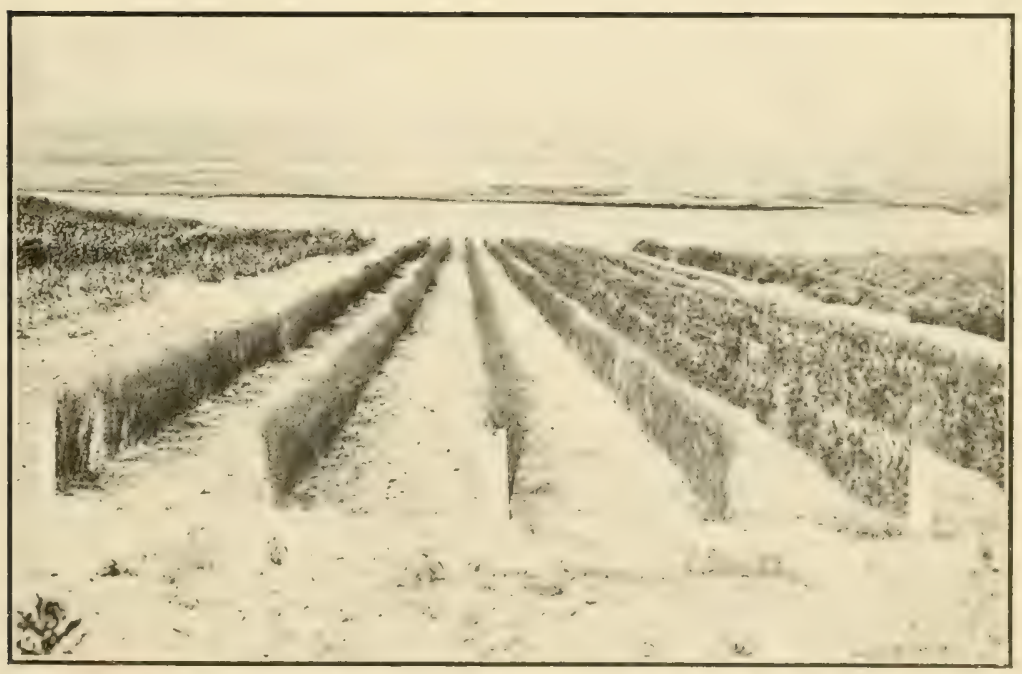

The two rows of Flax on the left from seed grown on the Elko Dry Farm the previous year. The next two rows from the same parent seed of the two rows on the left. Showing the advantage of planting seed grown under dry farm conditions. 



Millet-Barnyard
Millet-Broom Corn
Millet-Common
Millet-Golden
Millet-Siberian
Millet-Hungarian
Millet-Foxtail
Millet-Hog -
Millet-Japanese
Millet-Pearl

3. Peas and beans:

Green Canada Field

Golden Vine

17.2 bushels per acre

Earliest of All (garden)

14.3 bushels per acre

Spring Vetch 14 pounds from 246 -foot row

Cow peas-Whipoorwill Excellent stand; no definite report as to yield

Early Soja bean Seed did not germinate Seed did not germinate

In a comntry where hogs are raised on alfalfa pasture the necessity for some crop, furnishing food for goor finish ration, is apparent. Nothing better than field peas can be found, as pea-fed pork is more and more being sold at a substantial premium. Such being the ease it is encouraging to find that harly varieties of field peas can be grown with profit, by dry farming, in Nevada.

Spring retch and winter vetch form valuahle constituents for forage crops. A profitable combination is winter vetch and winter rye sown for green feed the following season.

Cow peas and soja heans have proven valuable crops in certain eountries. Our failure was due to poor seed, probably old.

4. Carrots, parsnips, onions, and potatoes:

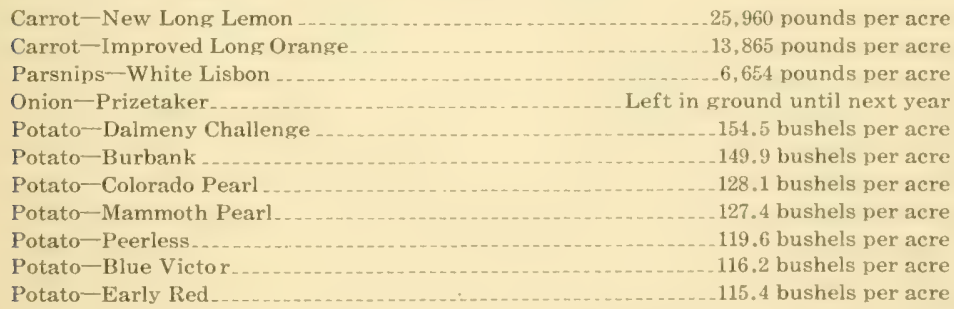

The potatoes were planted in rows three feet apart. In the row the hills strod two feet apart. The method of planting was hy sparle-a spade was thrust about 8 inches into the soil; hy hending the sparle over without withdrawing it opportunity was given to drop in the potatoes. When the spade was withdrawn the seed lay in moist soil at a proper depth. The increase in yield for 1912 was probably due to increase in precipitation and posilily to better anditions of the soil. Potatoes planted in soil previously smmmer fallowed, thus anserving moisture, should do better.

The quality of these potates, while varying with the variety, was uniformly excellent. In size the potatoes were what we maly call "of gent cooking size", not so large as those grown under irrigation, hut for all practical purposes the size and quality left mom for little fault-fincling.

5. The following crops came up and made good promise but were eaten down by rabbits: 


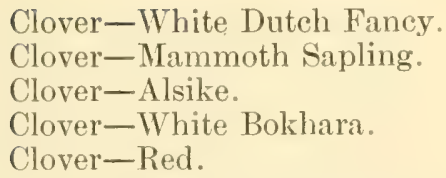

Alfalfa-Provence. Alfalfa-Kansas. Alfalfa- Western. Alfalfa-Grimm. Alfalfa-Sand Lucerne.

The following were sown, but the seed did not germinate:
Clover-Japan.
Grass-Orchard.
Clover-Burr.
Clover-Esparsetto.
Grass-Red Top.
Grass-Awnless Brome.

\section{Clover-Crimson.}

The failure of these to germinate must have been due to lack of moisture, as it is not likely that all the seed was bat. The rabhits furnish a constant menace to small plots of young clover.

6. Wheat, oats, barley, and flax:

Wheat-Blue Stem
Wheat-Pedigreed Defiance-21.5 bushels per acre, 60.3 pounds per bushel
Wheat-Kubanka
Oats-Sixty-Day
Oats-Minnis
Rye
Barley-Beardless
Flax

Of the Defiance wheat much good can be said. Not only was the stand uniform and the growth vigorous, but the plants indicaterl quality; the heads were long, spikelets well filled, and the plants many-stooled. The grain when threshed bore out the promise in the field. It was of a light and transparent amber, of good size, uniform and pronounced by millers to be of the highest flour producing type. It is the intention to multiply this grain. Kubanka was a very close second; lut Blue stem, while not poor, did not show the quality of the other two.

The Beardless barley was of excellent quality and yielded well. Fxamined in the sack the oats do not impresis one very favorably, heing light and apparently of large hull percentage.

'The flax gave good returns, the seed being of the best quality. It may prove a paying crop.

\section{Fall-Sown Crops}

Of these crops only three gave yields:

Wheat-Turkey Red....
Rye-No. 1
Rye-No. 13 . 23.2 bushels per acre, 61.1 pounds per bushel

The following gave poor returns, the stand being decidedly thin:

Oats-Winter Turf.

Wheat--1656.

Wheat-1559.

Wheat-White Australian.
Barley-Tennessee Winter.

Emmer-Black Winter.

Spelt.

Einkorn.

The ansideration of this extensive failure of the crop sown in the fall of 1911 leadis to some interesting possibilities. Probably we har hetter consider them separately:

(a) It will be remembered that the precipitation during the summer of 1911 was light, and that, while there was a fair amount during the winter of 1911, there had heen no summer fallow to conserve this moisture. Comsequently the seed sown that fall must have fallen in dry places; 
nor could there have been much soil moisture below to be brought up by packing.

(b) At the Dry Farm ('ongress at Lethhridge it was the comsensus of opinion that grain should not be planted at a greater depth than three inches. Below that was styled as below the nomal growth level. The autumn sown grain we are discussing was planted at from five to six inches. This is another possible cause of failure.

(c) From August 15 to September 1 is about the hest time to sow fall crops. The crop of the fall of 1911 was later than this, some of it much later. Even if germination did take place it was too late to secure the best stand to face the hardships of an Elko winter.

We feel that the experience was a good one in that it has demonstrated conclusively the necessity for conservation of soil moisture, for early sowing, aud for sowing at a normal depth. It may he stated that little of the grain actually appeared above gromol so that we may conclude that much of it failed to germinate. A little may have failed to winter over. Probably a emmbination of the three conditions ansed the (rop) failure.

The Turkey Red winter wheat was of outstanding quality showing marked hardness and fine color.

\section{Fall Seeding}

1. Small quantities of alfalfa seed, known to have been produced under adverse conditions, were sown. This seed did not come up. It should be stated that this was for demonstration purposes amol to decide the question as to fall seeding of alfalfa muder dry-farm conditions. The eight samples were from plants as hardy as could he fomm but the seed did not respond to fall planting - the explantion is probably that sufficient moisture was not available.

2. Wheats were sown under a variety of conditions:

(a) Turkey Red-Sown August 27, in duplicate plots; sown 30, 45, 60,75 and 90 pounds per acre. Up September 9.

(b) Turkey Red-Dry-farm seed; duplicate plots as in (a).

(c) Turkey Red-Dry-farm seed; 5 acres, 45 pounds per acre; sown September 5. Up September 16.

(d) Turkey Red-Not dry-farm seed; 1/2 acre, 45 pounds to acre.

(e) Kubanka-Duplicate plots; sown 30, 45 and 60 pounds per acre. Up September 9.

(f) Kubanka-Duplicate plots; sown 30, 45, 60, 75 and 90 pounds per acre.

(g) White Australian-Inplicate plots; somm :30 and 1.5 poumds. Ip September 5.

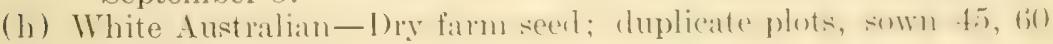
and 75 pounds per acre.

(i) Silver King-Duplicate plots; sown 30, 45 and 60 pounds per acre. Up September 13.

(j) Plots of Australian Winter wheats were sown on September 13. These have made a very favorable fall growth. The varieties were Bobs, Yandilla King, Cedar, and Federation.

(k) Four varieties of winter wheats, Eastern sexl, were sown on kep)tember 26. - These were Turkey Red, Nichigan Amber, Kharkov, and Dawson's Golden Chaff. The seeding was pretty late, but they may come ahead notwithstanding. 
3. Tests similar to those in 2 were made with other grains.

(a) Temnessee Winter Barley-Duplicate plots; sown $30,45,60,75$, and 90 pounds per acre. Up September 9 .

(b) Temnessee Winter Barley-Dry-farm seed; duplicate plots; sown 72,96 , and 108 pounds per acre.

(c) Rye No. 1-Duplicate plots; sown 42 and 56 pounds per acre; sown August 27. Up September 2.

(d) Rye No.3-Duplicate plots; sown 42 and 56 pounds per acre; sown August 27. Up September 2.

(e) Rye and Winter Vetch-Duplicate plots; sown 4.5 and 90 pounds per acre.

(f) Reel Rust Proof ()ats- Doulicate plots; sown 30, 45, and 60 pounds per acre.

(g) Emmer, spelt. Einkon-I)uplicate plots; sown tis pounds per acre.

The most of this fall seeding has been done in duplicate. A uniform depth of three inches has been maintained in seeding. In some cases the crop is known to be a spring one and the change is by way of experiment, notably in the case of Kubanka wheat. It will be noted that the seeding was practically all hefore september 15 . A visit in the early fall showed a splendid autumm stand and later reports have recorded gond progress. Conditions being normal, the crop sown in the fall of 1912 should make a satisfactory showing in 1913.

\section{COMMENT}

1. The outstanding feature of the dry-farm produce from the Nevada State Dry Farm has been extra quality. Samples of the grain, in sheaf and threshed, have been sent to different places, and in all cases their quality has excited much favorable comment. Yields may not be as bulky as under irrigation conditions, but quality is the factor that more than redeems lack of yield. It cannot but have great influence on commercial value of yield.

2. The work at Elko has heen much hampered by souirrels, rabints and hirls. In one your (1!11) over $200(0)$ gromel squirrels were trappeal and killed. It has been recorded that the rabbits keep the clover plots cropped to the ground. The birds rob the sheaves of grain and so materially reduce the yield, a bitter disappointment to the interested experimenter.

3. The crying need of the station is for a separator outfit. The plots mature irregularly and should be threshed as soon as they are mature, in order to reduce losses to a minimum. Under present conditions the produce from each plot is stacked separately to await the arrival of a large custom thresher. During the long wait the winds blow the loose straw and heads about and mix them up, and the conscientious experimenter must remove from three to six inches of debris from between the stacks at time of threshing. This reduces the yield report, already affected by inroads of the birds; besides there is always the danger of mixing varieties, to avoid which is the first commandment to the field husbandman.

\section{CULTURAL METHODS \\ Clearing the Land of Sagebrush}

In the preparation of sagebrush land the most difficult and expensive operation is that of removing the brush. When possible this is most 
easily accomplished by huming. By this proxess it is possible to renore the brush from several acres a day when the wind is farorahle. When done by hand one-half an acre a day is the average work of one man. When the brush is not thick and does not grow very high, the ground may he cleared sufficiently for plowing he railing the brush. This is a rapid method of removing the brush, but does not prove satisfactory where the brush is thick and high. The sugeloush grablersor mathines give very good satisfaction when sufficient power can be applied; however, in the thick high brush they do not work well unless operated with an engine.

At Elko after the nearly cleared land was plowed the sagebrush roots were removed immediately - that is, the same day-with spring plowing,

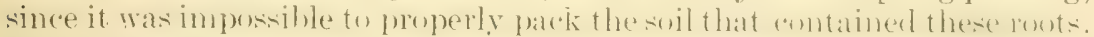
For this purpose the new alfalfa cultivator proved a very useful implement, especially with large roots. Where the roots were small and easily separated from the soil, the common smoothing-harrow or hayrake was used. Fall-plowed ground that was cleared of roots was left in the rough condition. In the spring the disk harrow will be used as soon as the ground can be worked, and this followed immediately by the smoothing harrow.

\section{Plowing}

The newly cleared ground was plowed to a depth of eight or ten inches. This brought all silgehrush routs to the surfares and also providerl a reservoir deep enough to catch all of the rainfall. Deep plowing is one of the most essential factors in preparing the seerl-bed, and generally the

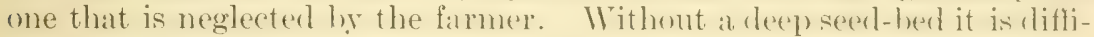
cult to store all of the water from the rain and snow.

In this State it is seldom possible to plow in early fall, and if not done in Octoler, November, or I)ecember, after the first heary rains, it must he postponed until early spring. The late fall plowing is strongly recommended since the greater portion of the precipitation eomes during the winter months, and in a rough condition the plowed ground is able to catch practically all of the rainfall.

\section{Plowing for Summer Fallow}

When the land is plowed in the spring for summer fallow, no more gromud was plowed in a day than could he disked, parked, and hammored the same day. Very little moisture can be depended upon during the summer and early fall, and every poscihle preantion must les taken to retain as much moisture as possible for starting the fall-serefted (arop. The summer-fallowerl land at the station which is to be used for spring granins was plowed up again in the fall in order to catch all of the winter rainfall, and in the spring it will be worked down in sultable condition for seeding.

An important point, not often recognized by dry-farmers, is the advisability, we might say the necessity, of lereling small inequalities in the surface of the field, so that the harrow in passing orer mat he able to seratch the entire surface and smooth over every spuare inch of the field. An ordinary leveler or drag, such a one as would be nsed under. irrigation conditions for leveling purposes, will meet all requirements.

\section{Timo of Seeding}

The time of seeding spring grains in this state will vary somewhat with the year and the locality. With an early spring the seeding may 
be done some time in March, but it should never be postponed until after the middle of April, since grain planted after this period is apt to be checked in growth by drouth before the roots are well established in the soil. It is a general plan to have all grain seeded by the first of April.

The time to sow fall grain will vary slightly with the locality, but the best results are obtained when the grain is sown before September 15 .

\section{Method of Seeding}

The single-disk drill is the inplement used for seeding. It distribute's the grain uniformly at a uniform depth and has a greater penetration than the double-disk drill or the shoe drills.

\section{Cultivation}

Considerable cultivation is necessary for either spring or winter grains: grown in this state. This is especially important during the early growth of the crop. The spring grains grown at the farm were given six cultiviltions with the smoothing harrow. Two of these cultivations were after moderately heavy rains and the others followed light rainfalls, each of which was sufficient to form a crust on the surface. The last cultivation was given when the plants were from ten to twelve inches high. Of course, some of the grain wats torn out and some almost Hattened to the ground, but the latter straightened up perfectly in a few days with littleor no injury. Thorough cultivation more than compensates for the small amount of moisture removed ly the young plants that are pulled out in cultivating. There is no question but that flattening grain that is ten to twelve inches high destroys some of the plants, but this can be overcone by the use of a smoothing cultivator instear of the common smoothing harrow. This implement is so constructed that it will not hend the grain when cultivated.

\section{Alternate Cropping and Fallowing}

Since the annual rainfall in most sections of the State is relatively small, it seems possible to grow crops on a given field only on alternate years, fallowing the ground when it is not eropped. Land that is fallowed must be kept free from weeds, for if allowed to grow they exhanst the soil of practically as much moisture as a grain crop, and in this way the fallow is not effective. It is a difficult task to keep some of the newly broken sagebrush land free from the tar-weed. This weed grow: from six to twenty-four inches high, spreads by means of underground stems, and it is thus very difficult to completely eradicate. New plants shoot up from the underground stems within a short time after they have been cut off near the surface of the ground. Their roots penetrate the soil to a great depth and are thus able to keep the plants supplied with moisture. The hest means of removing the tar-weed is by careful and continuous cultivation. This is probably best accomplished hy at knife weeder, which consists of a series of horizontal knives that run beneath the surface of the ground and eut the roots without bringing any moist soil to the surface.

\section{ORCHARD}

The young orchard, which had almost heen annihilated by cattle at the time of the accession of the property, has, as a result of care and pruning, made very satisfactory growth. The past season Ben Davis and Vellow Transparent apple trees bore fruit of high quality for the varieties. Bartlett pears were in bearing and two trees each of Green Gage plums and cherries were loalded with fruit, the plums heing of the finest quality. 


\section{Other Trees}

Seed of White Pine, Southern Pine, Northern Pitch Pine, Tamarack Pine, Austrian Pine, Island Pine, Pitch Pine, and Sugar Pine were planted. Of these varieties some of the Island Pine, Austrian Pine, and Pitch Pine germinated and made a growth of four to six inches.

\section{ECHOES FROM THE DRY FARM CONGRESS AT LETHBRIDGE, 1912}

\section{Crops}

Turkey Red seems to be the favorite winter wheat for dry-farming. It should be sown on summer-fallowed land, three pecks to the acre. Of the spring wheat, Durum type succeeds best and may be sown on fallow of the previous year, four pecks to the acre. Other early spring varieties do well when once established. Winter rye is a pretty sure crop. Sow five or six pecks to the acre. The following quantities of other grains may be sown: Spelt, five pecks; oats, four pecks; flax, two pecks; peas, five pecks; alfalfa, six pounds. Whenever practicable, drill sowing should be followed.

\section{Cultivation}

The aim should be to break the sod when it has the largest amount of moisture in it, say up to June 1. It may then be broken deeply and with a minimum of power. Breaking when the soil is dry calls for increase in the power used and generally causes a decrease in production. Besides there is smaller chance of sod decay. Plowing should be at least six inches deep, the succeeding plowings being a little deeper. Depth varies in different areas, but the greatest danger lies in plowing too shallow. After plowing one cannot have too much surface cultivation of the fallow land to keep down weeds and hold the moisture. Harrow the ground quickly after plowing and after every considerable rain. When the next spring opens, get on the ground early and harrow to prevent the loss of moisture. There is little gain from using a packer on fallcultivated land. This treatment does not tend to eatch the maximum of water and hold it, and in almost every case fall and winter precipitation will take care of the packing end of the problem.

Under dry-farm conditions the crop should be harrowed at least twice between sprouting and harvesting of the grain, the first just after the grain begins to show, unless in the case of alfalfa or flax, when the young plants should be a few inches high.

\section{Rotation}

This seems to be largely in the experimental stage and the rules vary with the amount of precipitation. Summer fallow has the first place, followed by winter wheat or other winter crop. It is then possible, by disking alone, to follow this crop by a crop of flax. One grain crop should not, as a rule, follow another grain crop immediately. The frequency of fallowing will be determined by the amount of precipitation available, and the necessity for weed eradication. There should be a definite aim to build up the humus content of the soil.

\section{Stock}

Many think that dry farming should include stock raising. This means that much of what is taken from the soil can be returned to it and the soil products utilized right on the farm. One experiment is the growth of soiling crops for stock maintenance on the dry farm. The manipulation of manure from the stock is also an important question. 


\section{Seed}

It was admitted by all that the seed grown under dry-farm conditions was of the best quality and was suitable for seed purposes when carried to more humid countries. Also the seed thus grown was bound to be free from weeds, due to the cultivation necessarily practiced. Much is still problematical as to the best method of growing alfalfa in subhumid climates.

\section{IMPORTANCE TO NEVADA}

No State, no province should be as vitally interested as Nevada in the problem of dry-farming. Nevada has a large percentage of her tillable area depending on some kind of dry-farming methods for success. It is advisable, without doubt, that prospective settlers on dry-farm areas should proceed with caution and that they should be careful about accepting too sweeping statements; but this only goes to prove the necessity for more light for an intelligent investigation of the State's possibilities. Given that the farmer is sure of the feasibility of a certain prospect, it is his duty to study the latest methods of soil culture, and it is the duty of the State to help him. Nor is soil culture the only thing - a leading proposition is to know the best varieties to sow, and where to get these varieties.

\section{FINANCIAL REPORT OF THE BOARD OF CONTROL OF THE STATE AGRICULTURAL EXPERIMENT DRY FARM, ELKO, NEVADA}

\section{Disbursements for 1911}

Salary, W. Sohlmản, foreman

Wages, extra help

Board of help

Board of Control, salary for 9 months

Seeds

Wire, building telephone line

Weather instruments

Surveying

Telephone

Horses (4)

Harness

Cows (2)

Implements

Incidental hardware

Threshing 1911 crop

Merchandise, Reinhard Company

New barn (40x60 with basement)

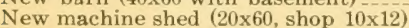

Posts for fence

Team and auto hire for 1911

Hay, 45,915 pounds

Oats, 16,510 pounds

Traveling expenses (G. H. True)

Stage, hauling packages, R. Streeter

Stationery

Smithing -

Old bill from 1910, Utah Implement Company ---

\section{Disbursements for 1912}

Salary, W. Sohlman, foreman

Wages, hired help

Board of help . .

Seeds

Hay for farm.

Travel, livery hire

Implements, etc.

Hay and grain

Smithing

Telephone -

Stage freight $\ldots$

Threshing crop of $1912 \ldots$

Expenses of Board of Control

One team

$\$ 1,200.00$

511.00

310.90

180.00

60.26

10.98

11.93

19.00

23.15

700.00

114.40

150.00

127.50

78.25

49.65

25.92

$2,237.06$

366.25

62.50

108.00

275.49

272.41

64.88

7.00

15.05

32.65

122.70

$\$ 1,200.00$

597.35

323.00

106.72

301.75

158.80

313.70

221.67

45.00

34.05

16.85

129.75

240.00

504.00 


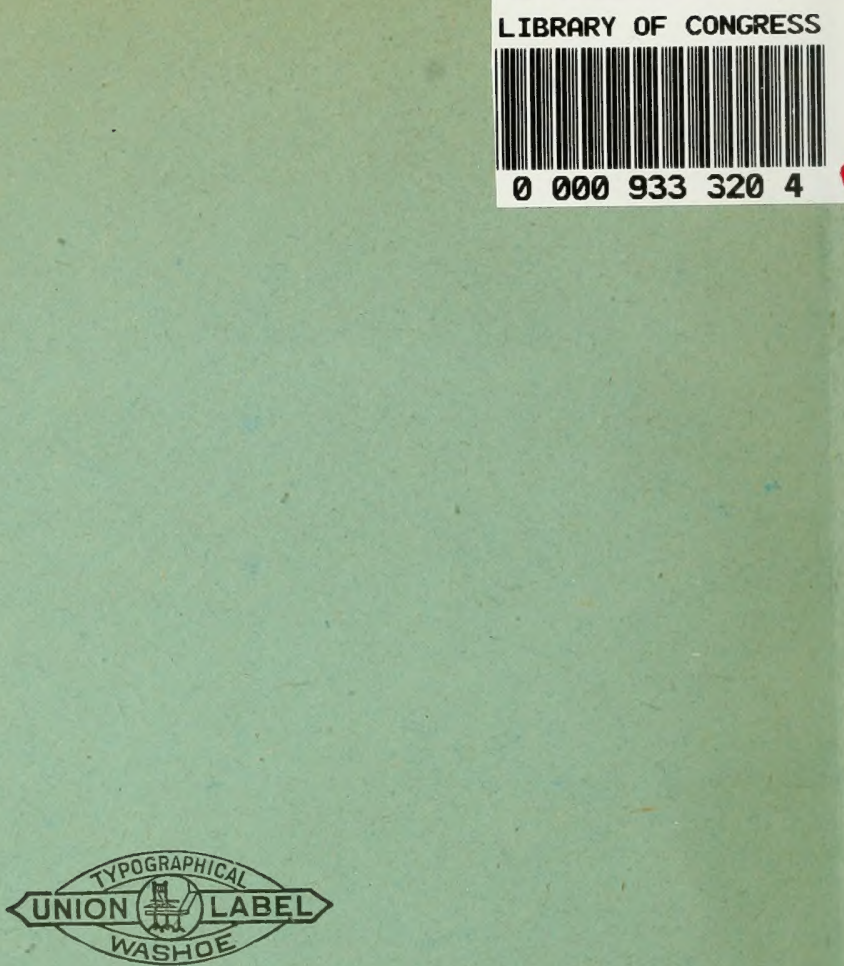